\title{
SILVER SPURS \\ FROM AN UNKNOWN SITE
}

\author{
Ivan Radman-Livaja \\ Archaeological Museum in Zagreb \\ Trg Nikole Šubića Zrinskog 19 \\ HR - 10000 Zagreb \\ iradman@amz.hr
}

UDK / UDC: 904:685.15"652"

Prethodno priopćenje / Preliminary communication

https://doi.org/10.52064/vamz.54.1.34

In the 1970s or the early 1980s an anonymous donator has gifted a pair of spurs to Zdenko Vinski, who had been in charge of the Mediaeval Department for decades. Unfortunately, the whereabouts of the discovery and the find spot are unknown and we may only speculate that these spurs were found somewhere in former Yugoslavia. They are nonetheless easily identifiable from a typological point of view, being late Roman spurs belonging to the so-called Leuna type. This set may be dated to the $4^{\text {th }}$ century $A D$. One may presume that this set was found in a grave, since Leuna-type spurs are more often than not either grave finds or finds discovered within Roman military sites and set

Key words:

spurs, Leuna type, $4^{\text {th }}$ century, grave finds

It is no coincidence that I have chosen this pair of spurs to be published in a volume dedicated to Željko Demo. As a matter of fact, he is the one who drew my attention to them a long time ago. While I have been thinking of publishing them ever since, and although we have discussed them on many occasions, years have passed and I have never been able to devote enough time to their study. They certainly constitute a remark able archaeological find, and the publication of Željko Demo's Festschrift is definitely an appropriate occasion to finally present them to scholars.

They are instantly recognizable as late-Roman spurs and, from a typological point of view, easily identifiable as being of the so-called Leuna type. By the $19^{\text {th }}$ century, such spurs had already been dated to late antiquity. ${ }^{1}$ In the first major publication devoted to ancient spurs by M. Jahn, they were assumed tlements, the latter finds usually not being full sets but single spurs or fragments. The find context is shrouded in mystery because the discovery did not occur under archaeological supervision and within the legal frame of professional field research. One may only conjecture what else could have been found in that grave but in any case, the discoverer, or one of the discoverers, contacted Zdenko Vinski, probably in order to get more information about his (or their) find. The late curator must have somehow convinced the anonymous finder to leave the spurs in the Museum but he probably never managed to obtain more information about the find spot and the archaeological context.

to be of Roman origin - wrongly, but understandably considering the available data at that time ${ }^{2}$ - and were classified as "Nietsporen", i.e. rivet spurs. ${ }^{3}$ After WWII a British scholar, H. de S. Shortt, wrote an overview of British finds, but he also used the opportunity to list analogous finds on the continent. ${ }^{4}$ The contribution of $\mathrm{E}$. Keller to the study of this type of spur provided a more secure dating within the $4^{\text {th }}$ century AD. ${ }^{5}$ Finally, a very detailed typology of such spurs was written over 40 years ago by $\mathrm{U}$. Giesler and still remains absolutely relevant. ${ }^{6}$

2 The type is certainly of Germanic origin, and only becomes more popular on Roman territory with the later variants $C$ and $D$, likely due to the increased presence of Germanic soldiers in the ranks of the Roman army (Giesler 1978, 28-32).

Jahn 1921, 77, Abb. 78-79; Giesler 1978, 5-7

Shortt 1959, 61-75.

Keller 1969, 201-206.

Giesler 1978. 
FIGURE 1. SEM-EDS preliminary metallographic analysis (made by D. Doračić).

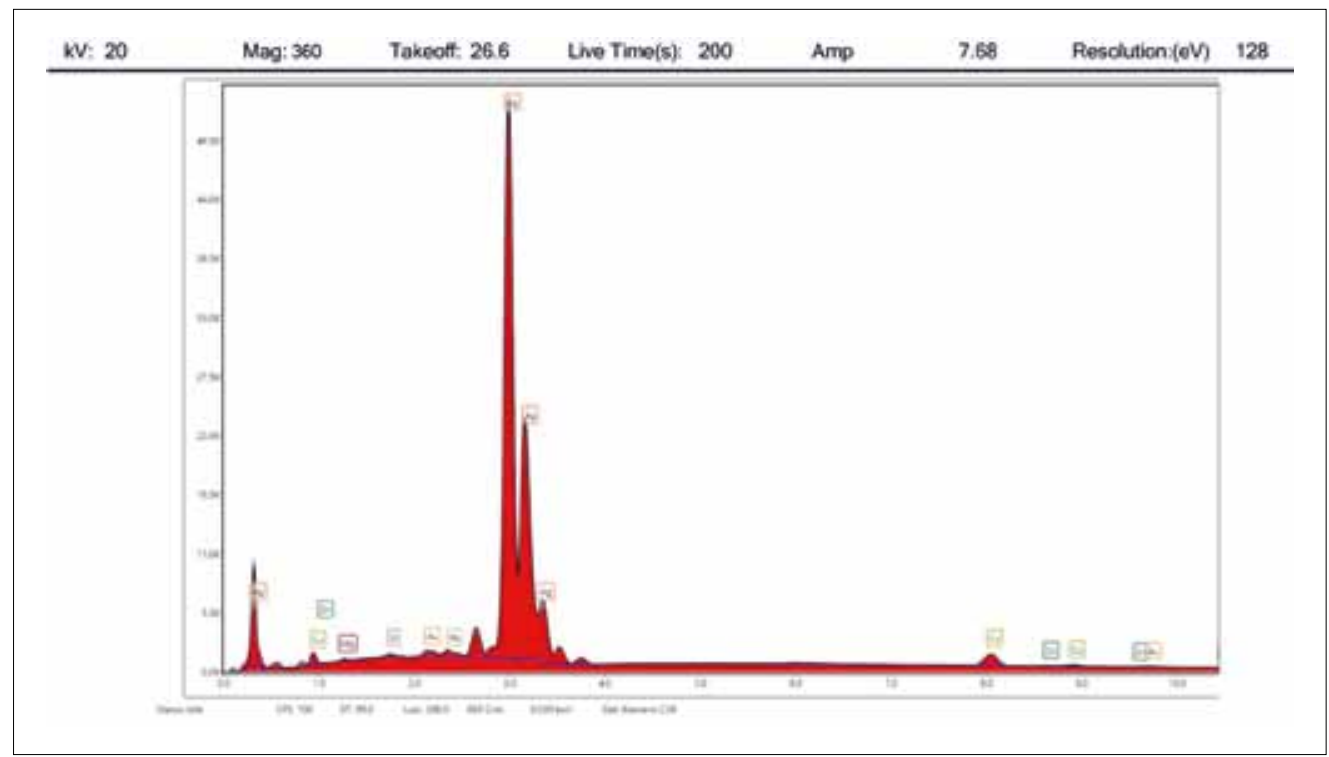

The general features of the Leuna type of spur are asymmetrical bow arms, as well as disc-shaped terminals with rivet holes, i.e. rivet plates or washers (Nietscheiben), which form the three holding points or attachments (Haltevorrichtungen), except for variant $D$, where the protruding central disc-shaped terminal has been replaced by a hook. Thus, Giesler suggested the definition of the Leuna type spur as the "Nietknopfsporn mit Dreipunkthalterung"? The spur would have been secured to the heel of the rider by means of one leather strap attached with rivets on both sides to circular rivet plates and ending with buckles on both ends, with another strap passing through the heel's disk or hook (depending on the variant) going around the rider's ankle and being secured with the buckles of the lower strap. $^{8}$

The first striking detail when one observes the pair of spurs from the AMZ collection is their material: they are made of silver alloy, a rather remarkable feature, although not utterly uncommon. ${ }^{9}$ According to the preliminary metallographic analysis done by Damir Doračić of the Analytical Laboratory of the Archaeological Museum in Zagreb, using a scanning electron microscope with the accompanying spectrometer of characteristic X-rays (SEM-EDS), the set is made of an alloy containing relatively pure silver and around $5 \%$ of copper (Fig. 1). The inlay used for the etched decoration on the bows of both spurs is niello, i.e. silver sulphide black paste (Fig. 2). They clearly are skilfully manufactured objects which might be described as luxury items.
Besides the two spurs, two small identical silver buckles belong to the same set. Both buckles, i.e. their frames, are D-shaped; their plates are rectangular with two small projections on each side in the central area, forming what might be described as serrated sides. Their overall length is $2.7 \mathrm{~cm}$, the $D$-shaped buckles being $1.3 \mathrm{~mm}$ long and the plates being $1.7 \mathrm{~cm}$ long. One prong is $1.4 \mathrm{~cm}$ long, while the other is $1.5 \mathrm{~cm}$ long.

All of these four items must have belonged to the same set, i.e. they must have been manufactured together, since there is no major difference whatsoever between the two spurs and the two buckles, except for minor discrepancies as far as the dimensions are concerned, and some slight dissimilarities in the decorative patterns. The set is not complete, however, since each spur would normally have two buckles. ${ }^{10}$ Besides, there are no metal strap ends, which are also present in certain complete sets found among grave finds. ${ }^{11}$

Both spurs are visibly asymmetrical, with one longer bow arm slightly bending outwards. As already pointed out, this is a common feature for Leuna-type spurs. They were not interchangeable, one being meant to be worn on the left foot and the other one on the right.

The bow arms of both spurs have a trapezoid cross-section and end in circular terminals, which were designed to house the now missing rivets (rivet plates, Nietscheiben). The width of the right spur bow is $6.7 \mathrm{~cm}$, while its central axis is approx. $4 \mathrm{~cm}$.
$7 \quad$ Giesler 1978, 7.

8 Giesler 1978, 17-21.
9 Somewhat more common for variant B (7 out of 28 finds in the list compiled by $U$. Giesler), unattested for variants $A$ and $C$, one known specimen so far among D-variant finds (Giesler 1978, 10-12, 14)

10 Giesler 1978, 17-20.

11 See, for instance, grave 3 in Leuna (Schulz 1953, 23-25, T. XVIII) or the find from Taurapilis in Lithuania, dated to the late $5^{\text {th }}$ or early $6^{\text {th }}$ century and ascribed by $U$. Giesler to her $E$ (west Baltic) variant, a later evolution of the Leuna-type spurs (Giesler 1978, 13-14, 53, Kat. 119). 


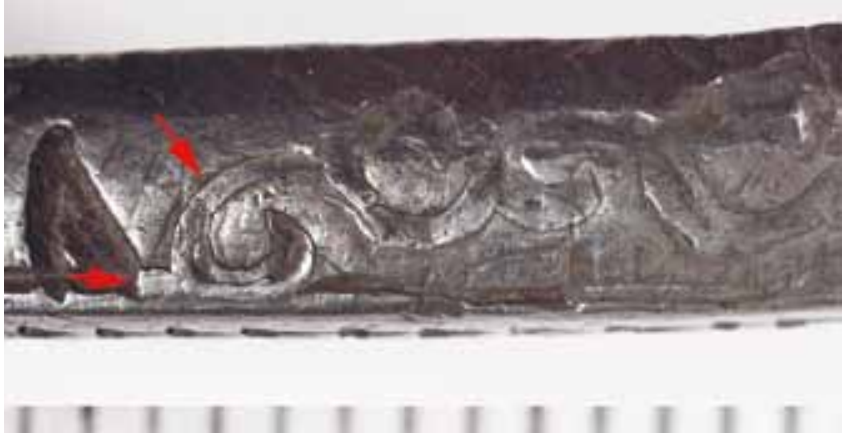

FIGURE 2. Niello inlay (photo by D. Doračić).

The width of the left spur bow is $7.1 \mathrm{~cm}$ and its central axis is also approx. $6 \mathrm{~cm}$.

The prick base (Dornbasis) is of a trapezoidal shape and tapers towards the heel hook (Fersenhaken), while the serrated lower end slightly protrudes under the bow. Below the hook is a rivet hole (this rivet still being preserved on the left spur). The pricks on both spurs are identical: they are cast in one piece and are composed of several segments. Both pricks, including the prick root, are $1.5 \mathrm{~cm}$ long. The prick root (Dornwurzel) is shaped in the form of two superimposed biconical disks, crowned by the prick itself (Dorn), which is composed of a lower part in the form of a truncated cone with a biconical base, followed by a conical point. The bow arms are fully decorated on the upper and lower sides. The decoration consists of two types of motif shallowly engraved on the surface and inlaid with niello. The bow-arm surface on the lower side of both spurs is a continuous line of wave crests, while the upper side is decorated with a combination of an abstract vegetal pattern, remindful of vine leaves, and $V$-shaped, i.e. triangular, notches. The vines only appear at the beginning of the longer upper side of the bow arms: the right spur has a motive of five vines followed by triangular notches till the end of the arm, i.e. till the circular terminal, while the left spur has the same combination, except for a slightly longer vine motif, i.e. seven vines. Interestingly, there are exactly 17 triangular notches on each bow arm, be it with or without vines. The notches, while having the same shape, are not symmetrical, some being narrower than others. The wave crests in the lower side are rather symmetrical, with 14 wave crests on each longer bow arm, and 11 wave crests on each shorter bow arm.

Inlaid decoration is far from being common on Leuna-type spurs. To my knowledge, only one bronze spur found in the River Seine in Paris and belonging to Giesler's D variant is decorated with silver inlay, and it is a much simpler pattern of incised V-shaped lines, covering in totality only the middle surface of the outer bow arm (the so-called Tannenzweigmuster, or fir-tree branch decoration pattern). ${ }^{12}$

12 Zschille, Forrer 1891, T. II, 11 a-b; Jahn 1921, 79, Abb. 83; Giesler 1978, 51 , Kat. 95.
These spurs clearly belong to Leuna spur variant $D$, as defined by $U$. Giesler, and incidentally the variant with the highest number of recorded finds. ${ }^{13}$ Besides features common to all the variants, this variant is defined by several specific features, most notably the heel hook at the prick base. Besides, the bow is fac eted with a triangular or trapezoid section (as in this particular case), while the rivet plates may have varying forms but are most often circular. The prick base may be swallowtail-shaped, rosette-shaped or trapeze-shaped (occasionally with a wavy or serrated bottom). The pricks of variant $D$ belong to several prick types, according to Giesler's typology, type 4 being the most common, followed by type $2 / 4$, while types 2,5 and 6 are only occasionally encountered. ${ }^{14}$ Our specimens have pricks which are mostly remindful of Giesler's prick type 2.

They are mostly made of copper alloy with iron pricks, but our specimens are entirely made of silver alloy, like the pair from Pašušvis in Lithuania. ${ }^{15}$ Variant $D$ can roughly be dated between the second half of the $3^{\text {rd }}$ century and the beginning of the $5^{\text {th }}$ century AD. ${ }^{16}$ However, when we take into consideration finds from well-defined archaeological contexts (like, for instance, dated graves), certain typological details could point to a somewhat narrower timeframe. The form of the prick, in this particular case pricks belonging to Giesler's type 2 , would likely point to a dating earlier than the mid- $4^{\text {th }}$ century $A D$, i.e. closer to the beginning of that century, even much earlier in the cases of variants $\mathrm{B}$ and $\mathrm{C} .{ }^{17}$ Smaller rivet plates would also belong to earlier D-variant spurs (second half of the $3^{\text {rd }}$ century AD and early $\left.4^{\text {th }}\right){ }^{18}$ The heel hooks of those specimens fall somewhere in between shorter hooks (typical of earlier D-variant spurs, second half of the $3^{\text {rd }}$ century AD and early $4^{\text {th }}$ ) and longer ones (more common of later D-variant spurs, $4^{\text {th }}$ century AD and early $\left.5^{\text {th }}\right) \cdot{ }^{19}$ If we are to rely on those typological indications, broadly dat ing this pair of spurs to the first half of the $4^{\text {th }}$ century AD would be an acceptable timeframe. More narrowly dating them to the first decades of the $4^{\text {th }}$ century AD might not be a farfetched as sumption, either.

Defining the type and variant of these spurs is not much of an issue, as a matter of fact. Even the dating, at least the broader timeframe, is fairly certain. But what was the find context? I cannot provide an answer to that question, I am afraid. The only information available to us, i.e. transmitted once upon a time to Željko Demo, is that an anonymous donator gifted this

13 The other name used by this author is "Westlich-provinzialrömische Variante", since most of the finds were discovered in the western Roman provinces, most notably Britain and the Rhine area, with some finds from Barbaricum, going as far as the Baltic lands, as well as occasional finds re corded in Italy, Raetia, Noricum and Pannonia (Giesler 1978, 12-13, T. 9; Kontny, Natuniewicz-Sekuła 2009, 155; Mackensen 2017, 180).

14 Giesler 1978, 9, Abb. 2, 13, 17

15 Giesler 1978, 51, Kat. 96

16 Giesler 1978, 22-23, 26.

17 This prick type is only seldom found in D-variant spurs (Giesler 1978, 23-25, 26, Tab. 5-7).

18 Giesler 1978, 23-25, 26, Tab. 5-7)

19 Giesler 1978, 23-25, 26, Tab. 5-7). 


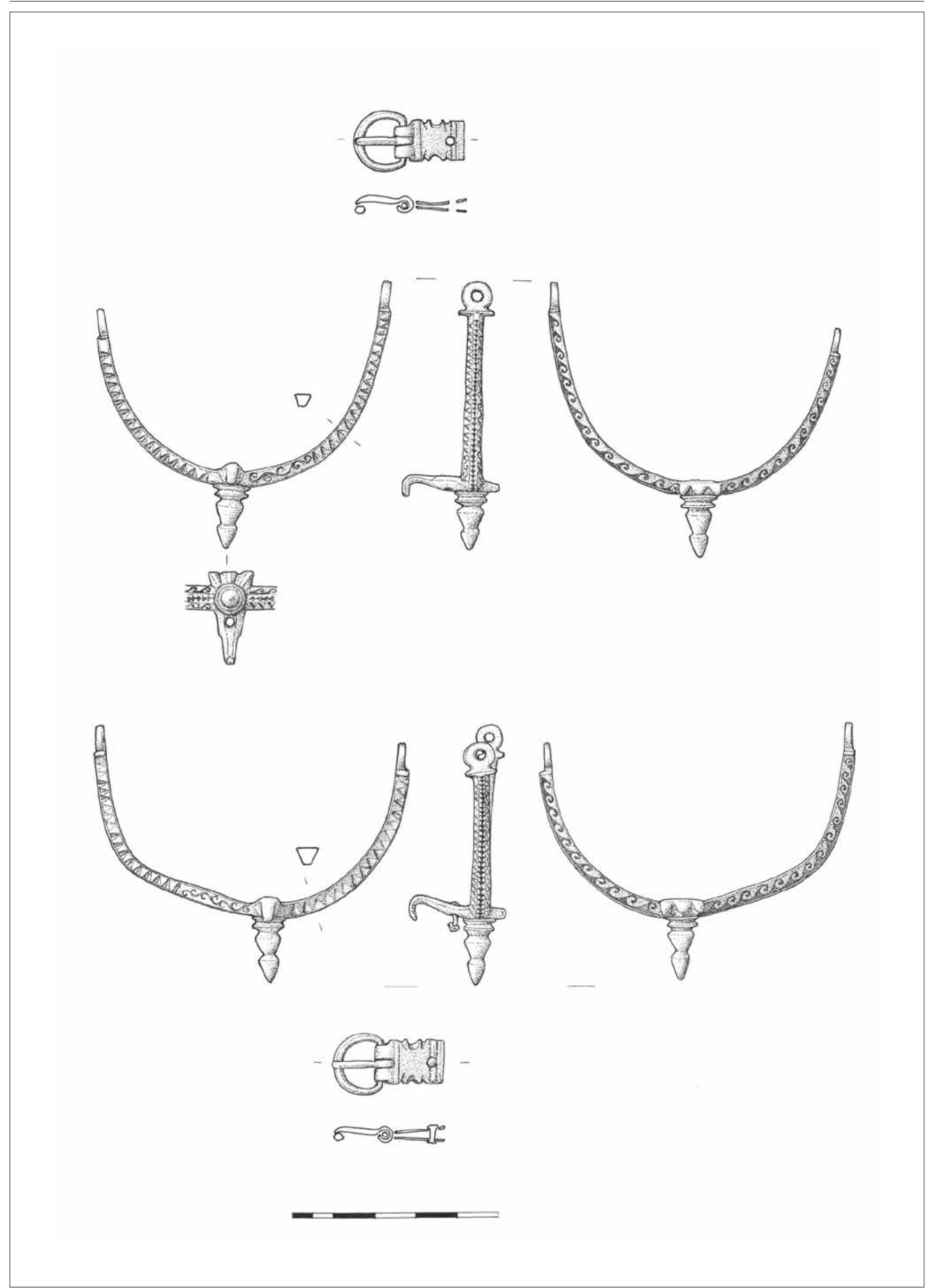




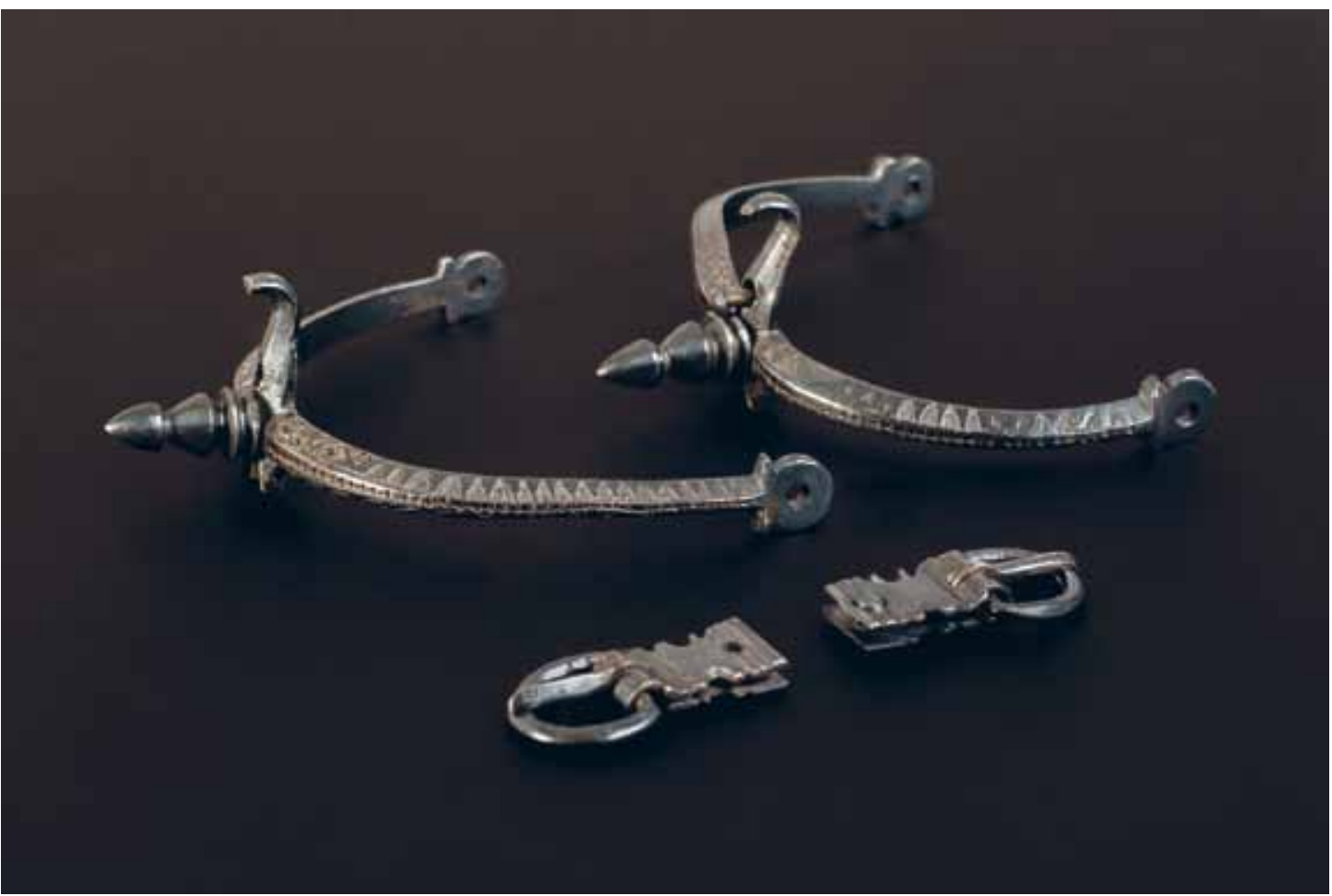

FIGURE 4. Spurs set (photo by I. Krajcar).

pair of spurs to Zdenko Vinski at one point, presumably in the seventies or early eighties. No mention whatsoever of this donation has been found in the museum archives, or in the notes left by the late Zdenko Vinski, who had been in charge of the Mediaeval Department for decades. We may only conjecture as to the whereabouts of the discovery and the find spot. Nonetheless, some assumptions may be more credible than others. The fact is that this set of spurs is almost complete. Two buckles are missing, perhaps also the strap ends, but one does not find such a set during field prospection or when excavating a rubbish pit. Finds of Leuna-type spurs are, more often than not, either grave finds or finds within Roman military sites and settlements. ${ }^{20}$ In the latter case, those are not full sets but single spurs or just fragments, i.e. items obviously lost or discarded at one point. One may thus reasonably presume that this set was found in a grave, but obviously not under archaeological supervision and within the legal framework of professional field research. One may only wonder what else could have been found in that grave; but, in any case, the discoverer, or one of the discoverers, contacted Zdenko Vinski, I imagine in order to get more information about his (or their) find. Our late curator somehow persuaded the anonymous lucky finder to leave the spurs in the museum, but we will probably never know whether Zdenko Vinski managed to get more information about the find spot and the archaeological context. In all probability, the spurs were not found outside the former Yugoslavia. Croatia comes first to mind, for obvious reasons, but Zdenko Vinski was a renowned medievalist, well known in the whole country (and abroad, as a matter of fact) and it is not unlikely at all that he may have been contacted by somebody from any other Yugoslav republic. While Vinski certainly was an eminent scholar with excellent professional contacts in Europe, especially in Germany and Austria, I find it unlikely that somebody would have risked bringing him such archaeological items from abroad, taking into account the border control procedures in effect in those times. As far as Yugoslavia is concerned, back in the time when U. Giesler published her seminal paper - a time when Vinski likely acquired these silver spurs - almost all Leuna-type spur finds were recorded in Slovenia, ${ }^{21}$ with one variant- $C$ find known from the Serbian province of Voivodina, from Torda more precisely, in the municipality of Zrenjanin (Nagybecskerek). ${ }^{22}$ Since then, two fragmented C-variant Leuna-type spurs have been recorded among finds from Teutoburgium (Dalj, Croatia), collected in the late $19^{\text {th }}$ and early $20^{\text {th }}$ century. ${ }^{23}$ Thus, these silver spurs may indeed have been found in one of those three countries, but their find spot will probably (and unfortunately) remain unknown. The total lack of data is frustrating, but they certainly deserve to be published, even if only to serve as an analogy and to complete the list of Leuna-type spurs.
20 Giesler 1978, 32-40; Müller 1989, 189-191; 2003, 128-129; Grezet 2014, 97-98; Zagermann 2014, 365; Mackensen 2017, 180-182.
21 For variant C, see Giesler 1978, 46-47, Kat. 41-45 (Drnovo), Kat. 52 (Ljubljana); for variant D, see Giesler 1978, 48-49, Kat. 68 (Ajdovščina), Kat. 72 (Celje).

22 Giesler 1978, 48, Kat. 64

23 Radman-Livaja 2005, 941-942 


\section{BIBLIOGRAPHY}

Giesler 1978 - U. Giesler, Jüngerkaiserzeitliche Nietknopfsporen mit Dreipunkthalterung vom Typ Leuna, Saalburg Jahrbuch 35, 1978, 5-56.

Grezet 2014 - C. Grezet (mit Beiträgen von M. Allemann, S. Cox, A. R. Furger, L. Grolimund und T. Nerini), Ausgrabungen in Kaiseraugst im Jahre 2013, Jahresberichte aus Augst und Kaiseraugst 35, 2014, 55-106.

Jahn 1921 - M. Jahn, Der Reitersporn, seine Entstehung und früheste Entwicklung, C. Kabitzsch, 1921.

Keller 1969 - E. Keller, Zur Datierung des Reitersporns von Seebruck, Bayerische Vorgeschichtsblätter 34, 1969, 201-206.

Kontny, Natuniewicz-Sekuła 2009 - B. Kontny, M. Natuniewicz-Sekuła, Spur from Myślęcin (?) as an odd piece in a puzzle, Barbaricum 8, 2009, 153-160.

Mackensen 2017 - M. Mackensen, Neue Evidenz zur Ausrüstung der equites stablesiani iuniores im spätrömischen Kastell Submuntorium/Burghöfe (Bayerisch-Schwaben), Bayerische Vorgeschichtsblätter 82, 2017, 171-184.

Müller 1989 - U. Müller, Ausgrabungen in Kaiseraugst im Jahre 1987, Jahresberichte aus Augst und Kaiseraugst 10, 1989, 177-194.

Müller 2003 - U. Müller (mit einem Exkurs von V. Vogel Müller und Beiträgen von L. Grolimund und A. Widmann und unter Mitarbeit von C. Saner), Ausgrabungen in Kaiseraugst im Jahre 2002, Jahresberichte aus Augst und Kaiseraugst 24, 2003, 115-130
Radman-Livaja 2005 - I. Radman-Livaja, Finds of Roman Military Equipment from Teutoburgium, in Visy, Z. (ed.), Limes XIX: Proceedings of the XIX International Congress of Roman Frontier Studies, University of Pécs, 2005, 939-951.

Schulz 1953 - W. Schulz, Leuna, Ein germanischer Bestattungsplatz der spätrömischen Kaiserzeit, Akademie-Verlag, 1953

Shortt 1959 - H. de S. Shortt, A provincial Roman spur from Longstock, Hants, and other spurs from Roman Britain, The Antiquaries Journal 39, 1959, 61-76.

Zagermann 2014 - M. Zagermann, Spätrömische Kleidungs- und Ausrüstungsbestandteile entlang der via Claudia Augusta in Nordtirol, Südtirol und im Trentino - Militarisierung der Alpen in der Spätantike?, Bericht der Römisch-Germanischen Kommission 95, 2014, 337-441.

Zschille, Forrer 1891 - R. Zschille, R. Forrer, Der Sporn in seiner Formenentwicklung, Teil I, P. Bette, 1891.

Zschille, Forrer 1899 - R. Zschille, R. Forrer, Der Sporn in seiner Formenentwicklung, Teil II, P. Bette, 1899. 